\title{
The Relationship between Scholarships and Student Success: An Art and Design Case Study
}

\author{
Natasha M. Ganem ${ }^{1}$ and Michelle Manasse ${ }^{2}$ \\ ${ }^{1}$ Department of Sociology, The University of Georgia, Athens, GA 30602, USA \\ ${ }^{2}$ Department of Sociology, Anthropology and Criminal Justice, Towson University, Towson, MD 21252, USA
}

Correspondence should be addressed to Natasha M. Ganem, nganem@uga.edu

Received 20 August 2010; Revised 3 May 2011; Accepted 22 May 2011

Academic Editor: Robert M. Carini

Copyright (C) 2011 N. M. Ganem and M. Manasse. This is an open access article distributed under the Creative Commons Attribution License, which permits unrestricted use, distribution, and reproduction in any medium, provided the original work is properly cited.

\begin{abstract}
The majority of studies investigating financial predictors of student success in higher education focus on liberal art schools and have investigated a limited number of conditioning variables in analyses. This study adds to the literature by exploring financial predictors of student success through a unique sample of students from an art and design college and by considering a number of variable interactions. Institutional scholarships emerged as the strongest predictor of student persistence, progression, and timely graduation in all models explored. Standardized test scores interacted with scholarship dollars in unique ways. Findings suggest that high test scorers may be at risk in an art and design institution and that scholarship dollars may mitigate this risk.
\end{abstract}

\section{Introduction}

Success in higher education is commonly defined by a student's persistence (i.e., continued enrollment in the institution), progression (i.e., successful accrual of credit hours), and timely graduation. The administration of financial aid to college students has been shown to facilitate such student success [1-12]. Financial aid for higher education consists of both need- and merit-based aid, in such forms as grants, loans, tuition remission, and private or institutional scholarships. Yet, between the years of 1995 and 2005, colleges and universities increased the total dollar amount spent on student aid by $95 \%$ [13]. Grant contributions rose $89 \%$, and, due to the marked increase in scholarships funded directly by individual institutions, schools were fiscally responsible for $41 \%$ of these expenditures [13] (These figures have been adjusted for inflation). Therefore, pecuniary variables, particularly institutionally funded scholarships, may play an increasingly large role in attempts to support student success in higher education.

Although a clear effect of financial aid has been established within the higher education literature [14], this effect has varied in direction and intensity [15-17], as well as across types of aid $[10,18]$ and characteristics of students
[4, 18-20]. Previous studies have therefore revealed a complex relationship between financial aid and student success, which warrants further investigation. The current study will add to this literature by examining the effect of merit-based institutional scholarships on persistence, progression, and timely graduation among a previously understudied population of art and design college students.

\section{Theoretical Background}

Universities have long relied on "traditional" measures of academic ability, such as standardized test scores, and high school grade point average (GPA), to predict college performance. Although high school GPA and standardized test scores do influence persistence, progression, and graduation [21-23], higher education research has identified a broad range of predictors for student success. Relevant variables include internal characteristics of the student, such as sex, race, academic goals, and academic skills, as well as external characteristics, such as institutional selectivity and various forms of financial support (see [10, 14, 24, 25]).

Robbins et al. [14] have conducted the most comprehensive meta-analysis to date on the predictors of college student success. By synthesizing traditional theories of educational 
persistence and motivational theories from the psychological literature (Tinto's [26] student integration theory posits that a student's social and academic integration into a college community influences their commitment to the institution and academic goals which, in turn, influences their decision to remain enrolled and progress towards graduation. This model focuses on the importance of student perceptions and self-reports. The second education model focuses on behavioral variables. Bean's $[27,28]$ model uses variables like contact with faculty (interaction) and time spent away from campus (lack of involvement) as the major predictors of attrition. Regarding motivational constructs, Robbins et al. drew on reviews by Covington [29] and Eccles and Wigfield [30] to identify motivation constructs as they related to drives (achievement motivation), goals (academic), expectancies (self-efficacy), and self-worth (general self-concept)), Robbins et al. [14] developed nine broad constructs that theoretically predict successful college outcomes. These constructs increase the likelihood of persistence to the extent that they increase the students' integration into the college community and provide intrinsic motivation for success. Among other variables that achieve these outcomes, Robbins et al. [14] highlight the importance of contextual influences, such as financial aid. Financial aid could have a direct effect on academic motivation if a student feels success is necessary to maintain a scholarship in the short term or allow the repayment of loans in the longer term. Aid could strengthen a student's integration into the community if the form of support, such as work-study or athletic scholarships, leads the student to connect with a large number of people across campus. In addition, the receipt of financial aid may create a kind of loyalty effect; students who choose to attend a college based on student aid have a higher likelihood of persistence, even when controlling for direct effects of aid [20].

As expected, financial support played a statistically significant role in predicting college persistence in Robbins et al.'s [14] meta-analysis. Financial aid was correlated with retention across the six studies used and 7,800 students evaluated, and, though academic self-efficacy and achievement motivation were the strongest predictors of cumulative college grade point average, financial aid sustained a moderate positive effect.

Multiple studies provide additional empirical evidence documenting the connection between financial aid and student success $[1,3-9,11,12]$. Yet, there is a great deal of inconsistency across research on financial aid and student outcomes [10,17]. Although much research suggests that financial aid has significant positive effects on persistence, other studies have shown no effect [31] or negative effects of financial aid $[15,16]$.

In two studies specifically focused on academic outcomes within elite universities, Alon $[18,19]$ argues that such inconsistencies arise because studies tend to conflate the variable of need-based aid eligibility with aid quantity. Alon [18] emphasizes the necessity of considering socioeconomic background in analysis by explaining: "On the one hand, the same factors that increase eligibility for financial aid, lowincome family status, are negatively related to persistence and graduation. On the other hand, amounts of financial aid are expected to increase persistence and graduation rates. Hence, the negative effect of need-based aid eligibility may mask the positive effect of aid quantity on college success" (299). When Alon $[18,19]$ separated the effects of these two factors, financial support positively influenced graduation. Grants and scholarships also had more pronounced effects in his study when compared to loans [18].

Alon's findings highlight a pattern identified in other studies that the type of aid administered to students may affect the relationship between financial support and academic success and account for some variation across studies [32-36]. For example, Hochstein and Butler [37] found that loans were negatively associated with college persistence, while grants had a positive effect on retention. Using a 1991 entering cohort sample of students eligible for merit scholarships at a college of fine arts, Schuh [36] found that, after accounting for SAT/ACT composite scores, high school GPA, and Stafford Loan eligibility, the amount of merit award was the only variable that significantly predicted graduation. This suggests that monies that do not need to be repaid may be particularly powerful in predicting student success.

Yet the relationship between financial aid and student success has been shown to vary across particular subsets of the student population. In a study of 466 private institutions (2002), Gansemer-Topf and Schuh [34] found that institutional scholarships positively influenced retention and graduation rates only for schools with low admissions selectivity. They argued that institutions that admit a higher percentage of applicants were more likely to enroll lowincome students who have a greater need for financial assistance; this echoes Alon's [18] findings that students from economically disadvantaged households are more sensitive to the impact of financial support. Research further suggests that minority students may be not only disproportionately likely to drop out due to loan repayment pressures but also disproportionately likely to respond positively to grant dollars (see $[18,38,39])$.

The current study will address the following research questions: do merit-based institutional scholarships influence persistence, progression, and timely graduation? Are there certain types of students who benefit (or benefit more) from such scholarships? This study will build on the ongoing conversation in several ways. First, this research will explore potential interactions between merit-based institutional scholarships and the "traditional" measures of student success, standardized test scores, and high school GPA, which has not yet been considered in the literature. This research will further add to the literature by examining the effect of institutionally funded aid on a sample of students from a private art and design college, a type of institution previously underrepresented within the literature.

\section{Research Methods}

3.1. Sample. The study sample was drawn from a private, four-year art and design college granting bachelor and master's degrees. The sample consisted of a cohort of 819 students entering as first-time freshmen during the fall quarters of the 2000-2001 and 2001-2002 academic years. 
This sample was selected for proper construction of the dependent variable capturing whether students had successfully graduated within six years of their matriculation (it is possible that this sample is unique from samples taken from other time periods due to the fact that these students were in their freshmen and sophomore years of college during the September 11, 2001 attack on the World Trade Center. Gallagher [40] reports that the 9/11 Tragedy may have "lowered the threshold" for students struggling with other problems, possibly precipitating or exacerbating dormant symptoms of psychological distress in students. This event therefore may have impacted this sample's ability to persist, progress, and graduate). Graduate students and transfer students were not included. Students who did not complete the Free Application for Federal Student Aid (FAFSA) were also not included. This was done so that estimated family contribution (EFC) could be controlled in analyses (The exclusion of such students from the sample created a conservative exploration of questions raised).

\subsection{Measures}

3.2.1. Independent Variable. The major independent variable in this study was institutional scholarships, defined as monies given to a student by the institution without the expectation of repayment. This was measured by total dollar amount of aid allotted to a student through institutional scholarships. Students received between $\$ 0$ and $\$ 120,267.50$ of institutional scholarship dollars during their 0 and 24 terms of enrollment. Most students received relatively small amounts of aid, which caused this variable to be right skewed. The natural $\log$ of aid was therefore taken to avoid unreliable results.

3.2.2. Dependent Variables. Persistence, progression, and graduation were the dependent variables investigated. Persistence was measured by the total number of hours that a student attempted (range: 0-301). Progression was measured by the total number of credit hours successfully earned by a student (range: 0-271). Graduation was measured by a dichotomous variable scored " 1 " if graduation occurred within six years of entry and " 0 " if not (63\% of the sample scored a " 1 " on this measure).

3.2.3. Control Variables. Given past research indicating the importance of other factors in student success, a number of control variables were taken into consideration. Race was controlled by a variable representing " 1 " for White, non-Hispanic students. The comparison category included minority students and those who did not mark their ethnicity on the FAFSA application. Also controlled through dummy variables were sex ( $1=$ female, $0=$ male $)$, a student's status as an in-state resident ( $1=$ in-state, $0=$ else), parental marital status $(1=$ married, $0=$ else), the education level of a student's father and mother $(1=$ attended college or graduate school, $0=$ else), and whether a student submitted a portfolio with their application $(1=$ yes, $0=$ no) (This variable was included because students who send portfolios may do so because they have more artistic experience and/or artist talent than their counterparts. Such students may therefore be more likely to persist, progress, and graduate). The natural log of the FAFSA's estimated family contribution calculation, or EFC, was used to control for economic resources available to the student and to act as a proxy for a student's socioeconomic background. A nontraditional approach was used to control for the impact of entrance test score on student success because a previous internal study on the art and design school's campus suggested that mid-range entrance test scorers were more likely to outperform very low as well as very high scorers. Dummy variables capturing SATs (or ACT converted scores) below 930, between 931 and 1020, 1111 and 1200 , and 1201 and higher were therefore compared to the left out category of 1021-1110. A similar approach was taken for the control of high school grade point averages (HS GPAs). Dummy variables capturing HS GPAs below 2.01, between 2.01 and 2.50, 2.51 and 3.00, and 3.01 and 3.5 were compared to the left out category of 3.51-4.0. This was done to determine whether the emphasis placed on very HS GPAs for admission to the college was necessary, given the institutional focus on art and design. Lastly, the natural log of the total dollar amount of need-based federal/state aid awarded to a student was captured to avoid conflating with the effect of institutional aid, the main independent variable of the study.

All analyses were conducted without the inclusion of cumulative college grade point average (CC GPA) as a control variable; this was done for multiple reasons. First, policy states that maintenance of a certain CC GPA is required for continued enrollment, accrual of hours, and graduation. This presented causal ordering issues in all regressions planned. Second, because CC GPA was tied to many of the institutional scholarships offered, it presented a moderate degree of multicollinearity. Third, CC GPA is not known at the time of admission, the point at which most institutional scholarships are given. This variable therefore cannot be used by administrators to determine who is most likely to be at risk upon admission to the college and upon the distribution of scholarship dollars. Fourth, in studies similar to this, CC GPA is typically used as a measure of student success. CC GPA is not used as a dependent variable in this study because it is possible that hours attempted, hours earned, and graduation within six years of entry are variables more generalizable across college campuses when compared to CC GPA.

\section{Results and Discussion}

4.1. Primary Analysis. To investigate the first research question regarding the impact of institutional scholarship dollars on persistence, progression, and graduation, independent and control variables were regressed onto the number of hours attempted and earned in an OLS regression (For a complete table of descriptive statistics, please see Table 3. Variable correlations are available upon request). Variables were then placed in a logistic regression onto a dichotomous variable grouping those students that graduated within six years of entry versus those that did not.

Table 1 indicates consistent results across models. Regarding the OLS regression in Models 1 and 2, the logged total dollar amount of institutional scholarship significantly 
TABLE 1: OLS and logistic regression of independent and control variables on persistence (Model 1: OLS), progression (Model 2: OLS), and graduation (Model 3: Logistic).

\begin{tabular}{|c|c|c|c|c|c|c|}
\hline \multirow[b]{2}{*}{ Constant } & \multicolumn{2}{|c|}{$\begin{array}{c}\text { Model } 1 \\
\text { Persistence }\end{array}$} & \multicolumn{2}{|c|}{$\begin{array}{c}\text { Model } 2 \\
\text { Progression }\end{array}$} & \multicolumn{2}{|c|}{$\begin{array}{c}\text { Model } 3 \\
\text { Graduation }\end{array}$} \\
\hline & $46.29^{* * *}$ & & $39.98^{* *}$ & & $-2.43^{* * *}$ & $(.09)$ \\
\hline Completed portfolio & 2.91 & $(.02)$ & 4.26 & $(.03)$ & .18 & $(1.20)$ \\
\hline Sex & -4.40 & $(-.03)$ & -3.69 & $(-.03)$ & -.19 & $(.83)$ \\
\hline Race & -4.62 & $(-.03)$ & -3.39 & $(-.03)$ & .07 & $(1.07)$ \\
\hline In-state status & 2.54 & $(.02)$ & 1.06 & $(.01)$ & -.01 & $(.99)$ \\
\hline Parental marital status & -4.80 & $(-.03)$ & -3.61 & $(-.02)$ & -.03 & $(.97)$ \\
\hline Father education level & 4.21 & $(.03)$ & 3.15 & $(.02)$ & .13 & $(1.13)$ \\
\hline Mother education level & 6.30 & $(.05)$ & 6.63 & $(.05)$ & .25 & $(1.29)$ \\
\hline Log of the average EFC & $5.11^{* * *}$ & $(.17)$ & $4.70^{* * *}$ & $(.16)$ & $.14^{* * *}$ & $(1.15)$ \\
\hline Log of total institutional aid & $4.78^{* * *}$ & $(.27)$ & $5.49 * * *$ & $(.31)$ & $.19^{* * *}$ & $(1.21)$ \\
\hline Log of total need-based aid & $4.83^{* * *}$ & $(.23)$ & $4.56^{* * *}$ & $(.22)$ & $.11^{* * *}$ & $(1.12)$ \\
\hline HS GPA: $\leq 2.0$ & -15.19 & $(-.05)$ & -17.95 & $(-.05)$ & -.44 & $(.64)$ \\
\hline HS GPA: 2.01-2.50 & -7.35 & $(-.04)$ & -11.58 & $(-.07)$ & -.39 & $(.68)$ \\
\hline HS GPA: 2.51-3.00 & -1.80 & $(-.01)$ & -5.00 & $(-.03)$ & -.26 & $(.77)$ \\
\hline HS GPA: 3.01-3.50 & -6.62 & $(-.05)$ & -8.94 & $(-.07)$ & -.28 & $(.76)$ \\
\hline Entrance score: $\leq 930$ & 1.22 & $(.01)$ & 1.30 & $(.01)$ & -.19 & $(.83)$ \\
\hline Entrance score: $931-1020$ & -1.12 & $(-.01)$ & -1.55 & $(-.01)$ & -.02 & $(.98)$ \\
\hline Entrance score: $1111-1200$ & $-21.41^{* *}$ & $(-.12)$ & $-22.55^{* * *}$ & $(-.13)$ & $-.90 * * *$ & $(.41)$ \\
\hline Entrance score: $\geq 1201$ & $-32.73^{* * *}$ & $(-.19)$ & $-30.22 * * *$ & $(-.18)$ & $-.98^{* * *}$ & $(.38)$ \\
\hline Adjusted $R^{2}$ & \multicolumn{2}{|c|}{.142} & \multicolumn{2}{|c|}{.152} & \multicolumn{2}{|c|}{.195} \\
\hline $\operatorname{Total}(N)$ & \multicolumn{2}{|c|}{819} & \multicolumn{2}{|c|}{819} & \multicolumn{2}{|c|}{819} \\
\hline
\end{tabular}

Note. Unstandardized regression coefficients shown. Standardized coefficients in parentheses in Models 1 and 2. Log odds in parentheses in Model 3.

${ }^{*} P \leq .05 .{ }^{* *} P \leq .01 .{ }^{* * *} P \leq .001$.

predicted both hours attempted and hours earned (M1: $t=6.91, P \leq .001$; M2: $t=8.13, P \leq .001)$. Standardized coefficients for Models 1 and 2 reveal that the impact of institutional aid was the strongest across all other independent variables (M1: $\beta=.27 ; \mathrm{M} 2: \beta=.31$ ). Regarding the logistic regression in Model 3, the effect of institutional scholarship was again statistically significant (Wald $=52.08, P \leq .001$ ). The odds that a student would graduate in this cohort increased by $21 \%$ with every unit increase of logged total institutional scholarship dollars. The anticipated impact of institutional scholarship on student success was therefore confirmed.

A few control variables consistently emerged as significant predictors of college success across all three regression models. Estimated family contribution (a proxy for socioeconomic background) and the logged total dollar amount of need-based financial aid sustained the most consistent and powerful effects, further promoting the idea that pecuniary variables are highly important when considering student success in private art and design colleges. The only other variable retaining a statistically significant impact on student success was entrance test score. It was expected that midrange scorers would be more likely to succeed when compared to low or high scorers. This was partially the case. Students scoring above 1110 were less likely to succeed than mid-range students scoring between 1021 and 1110. There was no difference in success when mid-range students were compared to students scoring below 1020. This finding confirmed a previous internal campus study and anecdotal knowledge shared by faculty members. This suggests that it is inappropriate to use entrance test score as predictor of success on this college campus and perhaps at other private art and design colleges nationwide. High scorers are significantly less likely to graduate when compared to mid-range scorers and low scorers are not necessarily different in their potential for success when compared to the mid-range group.

Other variables expected to impact student success surprisingly did not. Of particular note was that no significant effect was found for HS GPA. It is possible that artistic ability and individual creativity are better predictors of success at art colleges when compared to high school measures of academic ability. Though creativity and artistic ability are potentially captured by the presence or absence of a portfolio in a student's admission file, the presence or absence of a portfolio may instead be a reflection of student's organizational skills. Future studies from art institutions with solid portfolio rater reliability should investigate the effect of portfolio averages on success as opposed to the presence or absence of portfolios.

It should be noted that, while some independent and control variables significantly impacted persistence, progression, and graduation, these variables comprise only a moderate piece of a much larger puzzle. Of the regression models conducted, the OLS adjusted $R^{2} s$ indicate that the combination of variables used in analyses contribute only to $14 \%$ of the variance in campus persistence and $16 \%$ 
TABLE 2: OLS and logistic regression of independent, control, and entrance test score interaction variables on persistence (Model 1: OLS), progression (Model 2: OLS), and graduation (Model 3: Logistic).

\begin{tabular}{|c|c|c|c|c|c|c|}
\hline \multirow[b]{2}{*}{ Constant } & \multicolumn{2}{|c|}{$\begin{array}{c}\text { Model } 1 \\
\text { Persistence } \\
\end{array}$} & \multicolumn{2}{|c|}{$\begin{array}{c}\text { Model } 2 \\
\text { Progression }\end{array}$} & \multicolumn{2}{|c|}{$\begin{array}{c}\text { Model } 3 \\
\text { Graduation }\end{array}$} \\
\hline & $69.73^{* * *}$ & & $61.33^{* * *}$ & & $-2.17^{* * *}$ & $(.11)$ \\
\hline Completed portfolio & 1.62 & $(.01)$ & 2.88 & $(.02)$ & .16 & $(1.17)$ \\
\hline Sex & -4.65 & $(-.04)$ & -3.87 & $(-.03)$ & -.22 & $(.81)$ \\
\hline Race & -5.35 & $(-.04)$ & -4.22 & $(-.03)$ & .04 & $(1.04)$ \\
\hline In-state status & 5.28 & $(.03)$ & 4.01 & $(.03)$ & .10 & $(1.11)$ \\
\hline Parental marital status & -6.76 & $(-.04)$ & -5.52 & $(-.04)$ & -.16 & $(.85)$ \\
\hline Father education level & 5.78 & $(.04)$ & 4.70 & $(.03)$ & .23 & $(1.26)$ \\
\hline Mother education level & 6.68 & $(.05)$ & 7.13 & $(.05)$ & .29 & $(1.33)$ \\
\hline Log of the average EFC & $4.62 * * *$ & $(.15)$ & $4.20^{* * *}$ & $(.14)$ & $.13^{* *}$ & $(1.14)$ \\
\hline Log of total institutional aid & 1.56 & $(.09)$ & $2.62^{*}$ & $(.15)$ & $.12^{* *}$ & $(1.13)$ \\
\hline Log of total need-based aid & $4.69^{* * *}$ & $(.23)$ & $4.40^{* * *}$ & $(.21)$ & $.12^{* * *}$ & $(1.13)$ \\
\hline HS GPA: $\leq 2.0$ & -14.33 & $(-.04)$ & -17.01 & $(-.04)$ & -.53 & $(.59)$ \\
\hline HS GPA: 2.01-2.50 & -1.98 & $(-.01)$ & -6.02 & $(-.03)$ & -.14 & $(.87)$ \\
\hline HS GPA: 2.51-3.00 & .98 & $(.01)$ & -2.21 & $(-.01)$ & -11.56 & $(.00)$ \\
\hline HS GPA: $3.01-3.50$ & -1.85 & $(-.01)$ & -4.02 & $(-.03)$ & -19.63 & $(.00)$ \\
\hline Entrance score: $\leq 930$ & -16.01 & $(-.10)$ & -13.81 & $(-.09)$ & -.38 & $(.68)$ \\
\hline Entrance score: $931-1020$ & -18.06 & $(-.11)$ & -13.89 & $(-.08)$ & -.06 & $(.95)$ \\
\hline Entrance score: 1111-1200 & $-168.67^{* * *}$ & $(-.97)$ & $-175.09^{* * *}$ & $(-1.02)$ & $-.05^{* * *}$ & $(.95)$ \\
\hline Entrance score: $\geq 1201$ & $-346.26^{* * *}$ & $(-2.03)$ & $-355.04^{* * *}$ & $(-2.11)$ & $-.07 * * *$ & $(.93)$ \\
\hline IA* entrance score $\leq 930$ & 2.18 & $(.08)$ & 1.84 & $(.07)$ & .04 & $(1.04)$ \\
\hline IA* entrance score 931-1020 & 2.38 & $(.09)$ & 1.44 & $(.05)$ & -.01 & $(.99)$ \\
\hline $\mathrm{IA}^{*}$ entrance score $1111-1200$ & $19.35^{* * *}$ & $(.90)$ & $19.95^{* * *}$ & $(.94)$ & $1.37^{* * *}$ & $(3.93)$ \\
\hline IA* entrance score $\geq 1201$ & $37.49^{* * *}$ & $(1.91)$ & $38.71^{* * *}$ & $(2.00)$ & $2.25^{* * *}$ & $(9.52)$ \\
\hline Adjusted $R^{2}$ & \multicolumn{2}{|c|}{.247} & \multicolumn{2}{|c|}{.276} & \multicolumn{2}{|c|}{.361} \\
\hline Total $(N)$ & \multicolumn{2}{|c|}{819} & \multicolumn{2}{|c|}{819} & \multicolumn{2}{|c|}{819} \\
\hline
\end{tabular}

Note. Unstandardized regression coefficients shown. Standardized coefficients in parentheses in Models 1 and 2. Log odds in parentheses in Model 3.

${ }^{*} P \leq .05$. ${ }^{* *} P \leq .01 .{ }^{* * *} P \leq .001$.

of the variance of campus progression. While these values are of moderate sizes for this type of research, about $85 \%$ of the variance in persistence and progression is yet to be explained (In analyses not shown, CC GPA was included in all three models to see if this dissipated significant effects found and to see if this changed the predictive power of the models. Though $R^{2} \mathrm{~s}$ were increased (with these new models explaining $25-46 \%$ of the variance in student success) the only finding that differed from results presented in this paper was that male students were more likely to persist, progress, and graduate. Future research using art and design college students should investigate this issue regarding gender further). Regarding graduation, $20 \%$ of variance was explained (The Nagelkerke $R^{2}$ was used for all logistic regressions.): the model formulated would have correctly predicted graduation for $84 \%$ of the students who graduated and would have correctly predicted $40 \%$ of those that did not. It is likely that individual level indicators like social support, goals, and academic motivation as described by Robbins et al. [14] play the residual role in explaining a student's persistence, progression, and graduation. Data limitations constricted the analysis of such variables in this study.
4.2. Secondary Analysis. Given the research at other colleges and universities demonstrating the disparate effects of institutional scholarship given the type of aid recipient, additional analyses were conducted. Interactions between scholarship dollars and sex, race, socioeconomic background, HS GPA, and entrance test scores were investigated, but patterns did not align with what may have been expected from the past literature: sex, race, socioeconomic background, and HS GPA did not significantly moderate the impact of any scholarship extended (Results from these exploratory analyses are available upon request). This suggests that, for the sample studied, females are not more sensitive to the impact of scholarship dollars when compared to males, students of minority and unknown races are not more sensitive when compared to white students, those with low levels of estimated family contribution are not more sensitive when compared to those with high levels, and those with low HS GPAs not more sensitive when compared to those with high HS GPAs.

The only significant interaction effects found were interactions between scholarship dollars and high entrance test scores. These effects were consistent across models and can be seen in Table 2. Though previous analyses suggested that 
Table 3

\begin{tabular}{|c|c|c|c|c|c|}
\hline & $N$ & Minimum & Maximum & Mean & Standard deviation \\
\hline Number of hours attempted & 819 & 16 & 301 & 150.66 & 66.96 \\
\hline Number of hours earned & 819 & 0 & 271 & 142.14 & 66.04 \\
\hline Graduated in six (yes/no)? & 819 & 0 & 1 & .63 & .48 \\
\hline Completed portfolio & 819 & 0 & 1 & .49 & .50 \\
\hline Sex & 819 & 0 & 1 & .48 & .50 \\
\hline Race & 819 & 0 & 1 & .53 & .50 \\
\hline In-state status & 819 & 0 & 1 & .21 & .41 \\
\hline Parental marital status & 819 & 0 & 1 & .76 & .43 \\
\hline Father education level & 819 & 0 & 1 & .65 & .48 \\
\hline Mother education level & 819 & 0 & 1 & .65 & .48 \\
\hline Log of the average EFC & 819 & .00 & $\$ 11.51$ & $\$ 8.95$ & $\$ 2.21$ \\
\hline Log of total institutional aid & 819 & $\$ .00$ & $\$ 11.52$ & $\$ 5.97$ & $\$ 3.78$ \\
\hline Log of total need-based aid & 819 & $\$ .00$ & $\$ 12.10$ & $\$ 9.10$ & $\$ 3.21$ \\
\hline HS GPA: $\leq 2.0$ & 819 & 0 & 1 & .03 & .17 \\
\hline HS GPA: $2.01-2.50$ & 819 & 0 & 1 & .17 & .38 \\
\hline HS GPA: $2.51-3.00$ & 819 & 0 & 1 & .21 & .41 \\
\hline HS GPA: 3.01-3.50 & 819 & 0 & 1 & .36 & .48 \\
\hline Entrance score: $\leq 930$ & 819 & 0 & 1 & .22 & .42 \\
\hline Entrance score: 931-1020 & 819 & 0 & 1 & .19 & .39 \\
\hline Entrance score: $1111-1200$ & 819 & 0 & 1 & .18 & .38 \\
\hline Entrance score: $\geq 1201$ & 819 & 0 & 1 & .19 & .39 \\
\hline CC GPA & 819 & 0 & 4 & 3.03 & .76 \\
\hline
\end{tabular}

high test scorers were less likely to graduate when compared to mid-range scorers, it appears that institutional scholarship dollars can mitigate that effect. High scorers receiving comparatively large amounts of institutional aid were more likely to persist, progress, and graduate when compared to high scorers receiving lesser or comparably small amounts.

\section{Discussion}

This study used a unique sample of private art and design college students to examine the following questions: (1) do institutional scholarships influence persistence, progression, and graduation? And (2) do certain types of students benefit more/less from such scholarships? It was expected that scholarships would predict student success at the institution, but the second research question was exploratory.

Institutional scholarships significantly impacted student success across all measures: hours attempted, hours earned, and graduation within six years of entry. In fact, the impact of institutional scholarships was stronger than all other variables included in all models, though other awards for need-based aid and estimated family contribution were also important. Other traditional predictors of student success were either not significant predictors or they predicted success in unique ways. Sex, race, socioeconomic background, and high school GPA failed to significantly moderate the impact of institutional financial aid. However, while high test scorers (1111 and over) were less likely to succeed when compared to mid-range scorers (1021-1110), institutional scholarship dollars significantly mitigated this risk.
Although it is unclear why high test scorers are less likely to succeed, it is possible that high scorers have other institutional options available to them and may feel more freedom to take those options if not initially successful. Some evidence also suggests that those strong in leftbrain functioning (i.e., thinking logically and sequentially, processing grammar/vocabulary/mathematical equations) are weaker in right-brain functioning (i.e., thinking simultaneously and holistically, being imagistic, perceiving shapes/environments) [41-44]. While left-brain functioning is generally tested by standardized entrance exams, an art- and design-focused environment generally requires high right-brain functioning. Standardized test scores may therefore fail to account for the type of academic ability necessary for success in an art and design environment. The finding that high test scorers receiving merit-based scholarships were more likely to succeed than those not receiving aid may reflect that scholarship recipients are more highly motivated and therefore more likely to succeed. Those receiving scholarship dollars may also feel a heightened commitment to the school if they chose it based on the "best deal" offered [20]. Overall, the above findings indicate that financial support is essential for student success at private art and design colleges and that this is especially the case for high test scorers.

The above findings should be viewed in the context of the study's limitations, which suggest avenues for future research. Due to data limitations, a number of factors previously identified as predictors of student success could not be included in the regression models. Future research should 
consider the role of variables such as academic motivation, academic skills, and social support [14] on private art and design college campuses and the extent to which these variables interact with the effect of institutional aid on student success. In addition, because this study focuses on only one cohort within one institution, the model needs to be validated within other cohorts and at other private art and design colleges nationwide to determine the generalizability of findings. This study suggests that predictors of success on private art college campuses differ from predictors of success on liberal arts campuses, but further research is necessary to explore the nature of these differences.

This study contributes to the literature in three major ways. First, only Schuh [36] has questioned the relationship between financial aid, scholarships, and student success through the use of a sample which does not employ traditional liberal art students. This study corroborates his findings and extends their generalizability from a public arts college to a private arts college. This is important as many authors have cautioned against generalizing study findings to various campuses with different types of students or campus climates (e.g., $[18,36,45-48])$. Second, this study explored the interaction of high school GPA and entrance test scores with institutional aid, two never before explored interactions. Third, though additional replication is needed, this study highlights the fact that the predictors of student success at private art and design colleges may differ from traditional liberal art colleges. Institutional scholarships, need-based aid, and estimated family contribution seem to be variables of high impact, while other traditional variables play little to no role in predicting persistence, progression, and graduation.

\section{Disclosure}

This paper has not been published and is not currently being considered for publication elsewhere.

\section{References}

[1] A. F. Cabrera, A. Nora, and M. B. Castañeda, "The role of finances in the persistence process: a structural model," Research in Higher Education, vol. 33, no. 5, pp. 571-593, 1992.

[2] R. Chen and S. L. DesJardins, "Exploring the effects of financial aid on the gap in student dropout risks by income level," Research in Higher Education, vol. 49, no. 1, pp. 1-18, 2008.

[3] S. L. DesJardins, D. A. Ahlburg, and B. P. McCall, "An event history model of student departure," Economics of Education Review, vol. 18, no. 3, pp. 375-390, 1999.

[4] J. P. K. Gross, D. Hossler, and M. Ziskin, "Institutional aid and student persistence: an analysis of the effects of institutional financial aid at public four-year institutions," Journal of Student Financial Aid, vol. 37, no. 1, pp. 28-39, 2007.

[5] M. B. Paulsen and E. P. St. John, "The financial nexus between college choice and persistence," in Researching Student Aid: Creating an Action Agenda, R. Voorhees, Ed., Jossey-Bass, San Francisco, Calif, USA, 1997.

[6] E. P. St. John, "Price response in persistence decisions: an analysis of the high school and beyond senior cohort," Research in Higher Education, vol. 31, no. 4, pp. 387-403, 1990.
[7] E. P. St. John, "Workable models for institutional research on the impact of student financial aid," Journal of Student Financial Aid, vol. 22, no. 3, pp. 13-26, 1992.

[8] E. P. St. John, J. Oescher, and S. Andrieu, "The influence of prices on within-year persistence by traditional college-age students in four-year colleges," Journal of Student Financial Aid, vol. 22, no. 1, pp. 27-38, 1992.

[9] L. D. Singell, "Come and stay a while: does financial aid effect retention conditioned on enrollment at a large public university?" Economics of Education Review, vol. 23, no. 5, pp. 459471, 2004.

[10] L. Singell Jr. and M. Stater, "Going, going, gone: the effects of aid policies on graduation at three large public institutions," Policy Sciences, vol. 39, no. 4, pp. 379-403, 2006.

[11] D. G. Terkla, "Does financial aid enhance undergraduate persistence?" Journal of Student Financial Aid, vol. 15, no. 3, pp. 11-18, 1985.

[12] G. Thomas, "College characteristics and black students' four year college graduation," Journal of Negro Education, vol. 50, pp. 328-345, 1981.

[13] College Board, Trends in Student Aid, New York, NY, USA, 2007.

[14] S. B. Robbins, K. Lauver, H. Le, D. Davis, R. Langley, and A. Carlstrom, "Do psychosocial and study skill factors predict college outcomes? A meta-analysis," Psychological Bulletin, vol. 130, no. 2, pp. 261-288, 2004.

[15] E. P. St. John and J. B. Starkey, "An alternative to net price: assessing the influence of prices and subsidies on within-year persistence," Journal of Higher Education, vol. 66, pp. 156-186, 1995.

[16] A. C. Dowd and T. Coury, "The effect of loans on the persistence and attainment of community college students," Research in Higher Education, vol. 47, no. 1, pp. 33-62, 2006.

[17] L. Horn and K. Peter, What Colleges Contribute: Institutional Aid to Full-Time Undergraduates Attending 4-Year Colleges and Universities, National Center for Education Statistics, Washington, DC, USA, 2003.

[18] S. Alon, "The influence of financial aid in leveling group differences in graduating from elite institutions," Economics of Education Review, vol. 26, no. 3, pp. 296-311, 2007.

[19] S. Alon, "Model mis-specification in assessing the impact of financial aid on academic outcomes," Research in Higher Education, vol. 46, no. 1, pp. 109-125, 2005.

[20] E. P. St. John, M. B. Paulsen, and D. F. Carter, "Diversity, college costs, and postsecondary opportunity: an examination of the financial nexus between college choice and persistence for African Americans and Whites," Journal of Higher Education, vol. 76, no. 5, pp. 545-569, 2005.

[21] A. W. Astin, W. Korn, and K. Green, "Retaining and satisfying students," Educational Record, vol. 68, no. 1, pp. 36-42, 1987.

[22] C. W. Kern, N. S. Fagley, and P. M. Miller, "Correlates of college retention and GPA: learning and study strategies, testwiseness, attitudes, and ACT," Journal of College Counseling, vol. 1, no. 1, pp. 26-34, 1998.

[23] R. S. Levitz, L. Noel, and B. J. Richter, "Strategic moves for retention success," in Promising Pactices in Recruitment, Remediation, and Retention, G. H. Gaither, Ed., pp. 31-50, JosseyBass, San Francisco, Calif, USA, 1999.

[24] M. T. Harmston, "Cross-validation of persistence models for incoming freshman," Association for Institutional Research, no. 93, 2004.

[25] V. Tinto, Leaving College: Rethinking the Causes and Cures of Student Attrition, University of Chicago Press, Chicago, Ill, USA, 2nd edition, 1993. 
[26] V. Tinto, "Dropout from higher education: a theoretical synthesis of recent research," Review of Educational Research, vol. 45, pp. 89-125, 1975.

[27] J. P. Bean, "Dropouts and turnover: the synthesis and test of a causal model of student attrition," Research in Higher Education, vol. 12, no. 2, pp. 155-187, 1980.

[28] J. P. Bean, "The application of a model of turnover in work organizations to the student attrition process," Review of Higher Education, vol. 6, pp. 129-148, 1983.

[29] M. V. Covington, "Goal theory, motivation, and school achievement: an integrative review," Annual Review of Psychology, vol. 51, pp. 171-200, 2000.

[30] J. S. Eccles and A. Wigfield, "Motivational beliefs, values, and goals," Annual Review of Psychology, vol. 53, pp. 109-132, 2002.

[31] A. Braunstein, M. McGrath, and D. Pescatrice, "Measuring the impact of financial factors on college persistence," Journal of College Student Retention, vol. 2, pp. 191-203, 2001.

[32] A. W. Astin, What Matters in College? Four Critical Years Revisited, Jossey-Bass, San Francisco, Calif, USA, 1993.

[33] J. Cofer and P. Somers, "A comparison of the influence of debtload on the persistence of students at public and private colleges," Journal of Student Financial Aid, vol. 30, no. 2, pp. 39-58, 2000.

[34] A. M. Gansemer-Topf and J. H. Schuh, "Institutional grants: investing in student retention and graduation," Journal of Student Financial Aid, vol. 35, no. 3, pp. 5-20, 2005.

[35] L. W. Perna, "The contribution of financial aid to undergraduate persistence," Journal of Student Financial Aid, vol. 28, no. 3, pp. 25-40, 1998.

[36] H. Schuh, "Measuring the cost effectiveness of financial aid from an institutional perspective: a case study," North American SCRABBLE Players Association Journal, vol. 37, no. 2, pp. 414-427, 2000.

[37] S. K. Hochstein and R. R. Butler, "The effects of the composition of a financial aid package on student retention," Journal of Student Financial Aid, vol. 13, no. 1, pp. 21-27, 1983.

[38] R. Chen and S. L. DesJardins, "Investigating the impact of financial aid on student dropout risks: racial and ethnic differences," Journal of Higher Education, vol. 81, no. 2, pp. 179-208, 2010.

[39] D. Kim, "The effect of loans on students' degree attainment: differences by student and institutional characteristics," Harvard Educational Review, vol. 77, no. 1, pp. 64-100, 2007.

[40] R. P. Gallagher, "The psychological impact of 9-11 on college students and suggestions for how counseling centers can prepare for war and/or future terroristic attacks," Commission for Counseling and Psychological Services Newsletter, Spring Issue, 2003.

[41] J. F. Iaccino, Left Brain-Right Brain Differences: Inquiries, Evidence, and New Approaches, Lawrence Erlbaum Associates, Hillsdale, NJ, USA, 1993.

[42] B. McCarthy, The 4mat System Research: Reviews of the Literature on the Differences and Hemispheric Specialization and Their Influence on Learning, Excel, Barrington, Ill, USA, 1996.

[43] S. P. Springer and G. Deutsch, Left Brain, Right Brain, W.H. Freeman, New York, NY, USA, 1993.

[44] E. P. Torrance, "Hemisphericity and creativity," Journal of Research and Development in Education, vol. 15, no. 3, pp. 2937, 1982.

[45] D. L. Basch, "Private colleges' pricing experience in the early 1990s: the impact of rapidly increasing college-funded grants," Research in Higher Education, vol. 38, no. 3, pp. 271-296, 1997.
[46] R. P. Huff, "Facilitating and applying research in student financial aid to institutional objectives," in Studying the Impact of Student Aid on Institutions, R. H. Fenske, Ed., pp. 5-16, JosseyBass, San Francisco, Calif, USA, 1989.

[47] G. James and S. S. Mahajan, "Using scholarship management research to optimize the impact of scholarship funds," in Proceedings of the Annual Forum of the Association for Institutional Research, 2004.

[48] P. Somers, "The influence of price on year-to-year persistence of college student," North American SCRABBLE Players Association Journal, vol. 33, pp. 94-104, 1996. 


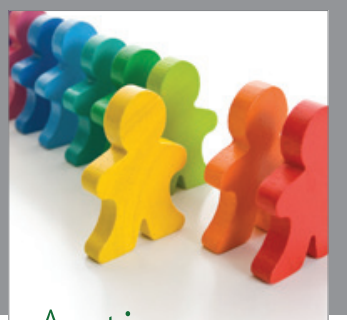

Autism

Research and Treatment
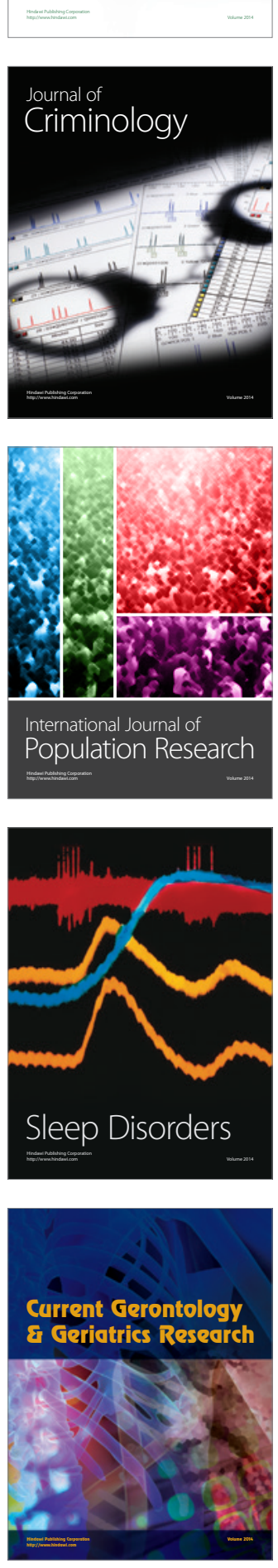
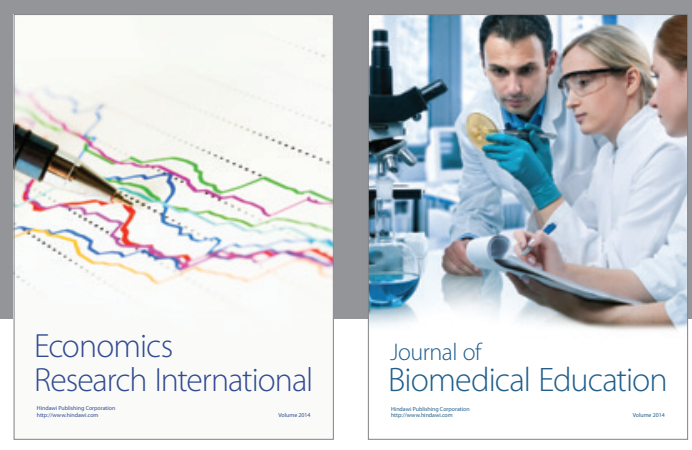

Journal of

Biomedical Education

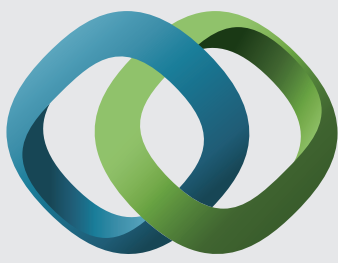

\section{Hindawi}

Submit your manuscripts at

http://www.hindawi.com
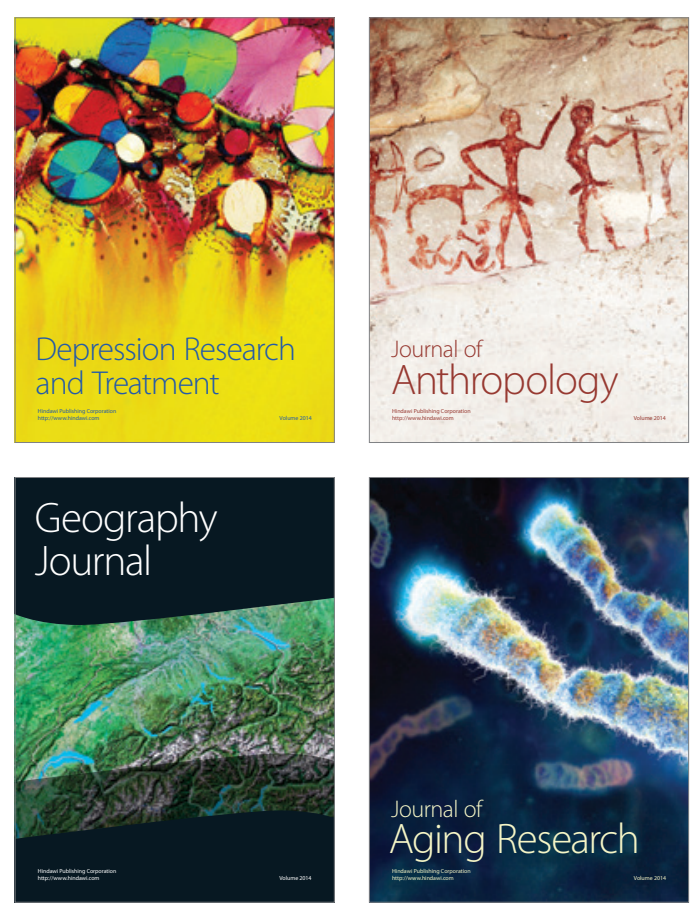

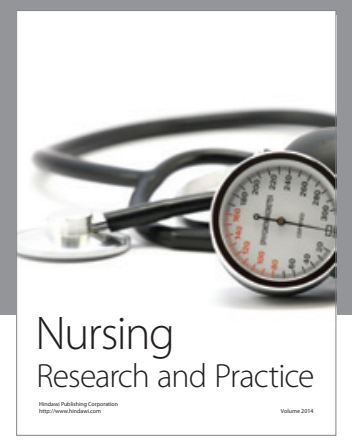

Nursing

Research and Practice

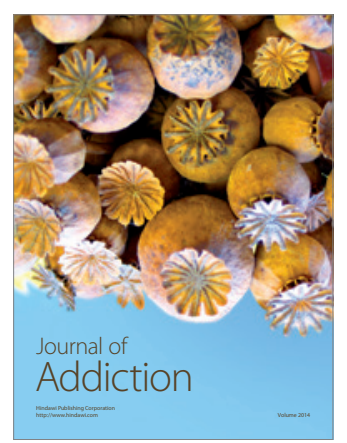

Child Development

Research

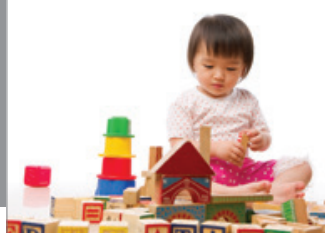

迥
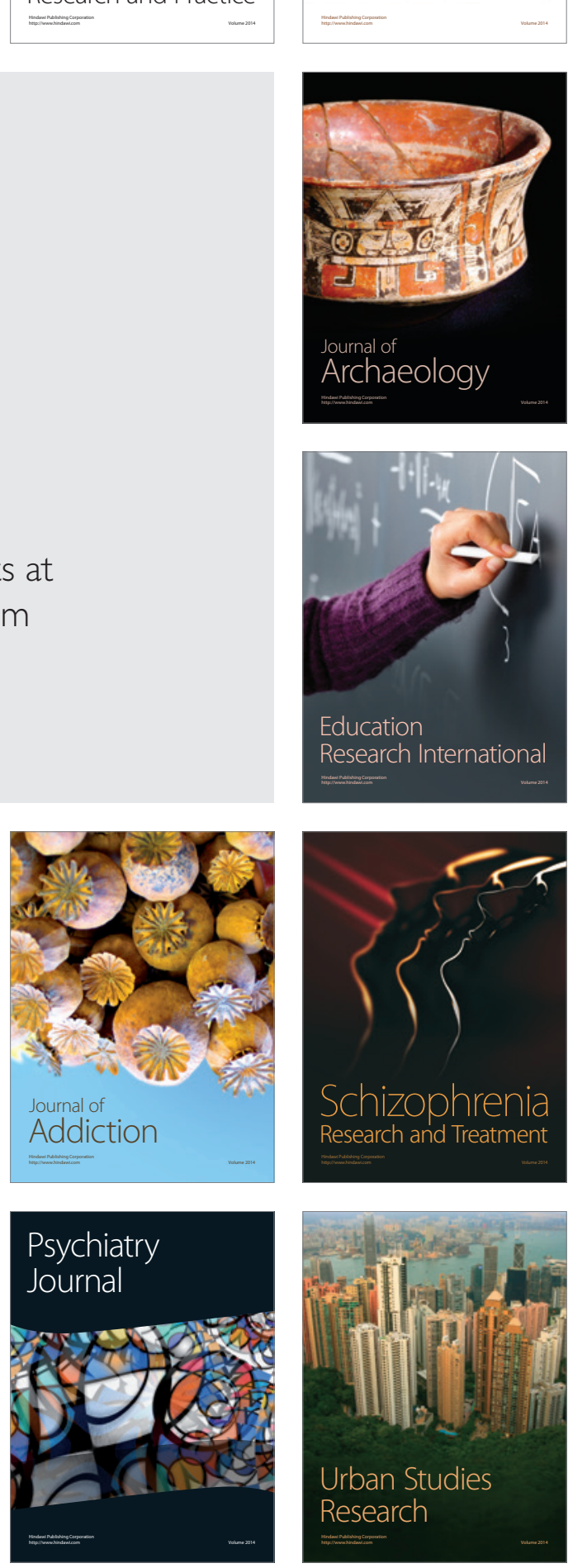